\title{
A prospective study demonstrating the effect of $5 \%$ povidone-iodine application for anterior segment intraocular surgery in Paraguay
}

\author{
Estudio prospectivo demostrando el efecto de la instilación de \\ yodo povidona al 5\% previo a cirugía de segmento anterior en Paraguay
}

\author{
Lorena P. Quirog'a \\ Van Lansingh ${ }^{2}$ \\ Florentina Laspina ${ }^{3}$ \\ Margarita Samudio $^{4}$ \\ Jenny Stanley ${ }^{5}$ \\ Herminia Miñ̃o de Kaspar ${ }^{6}$ \\ Dióg'enes Cibils ${ }^{7}$ \\ Pablo Cibils ${ }^{8}$
}

\begin{tabular}{l} 
ABSTRACT \\
\hline Purpose: To determine the conjunctival bacterial flora in cataract surgery \\
patients and the effect of presurgical irrigation with $5 \%$ povidone-iodine \\
solution. Methods: Three samples from the inferior conjunctival fornix of \\
the eye to be operated were obtained at baseline before washing $\left(\mathrm{T}_{0}\right)$ with \\
$10 \mathrm{ml} 5 \%$ povidone-iodine solution, immediately after washing $\left(\mathrm{T}_{1}\right)$, and \\
upon completion of surgery $\left(\mathrm{T}_{2}\right)$. Bacteria from the samples were inoculated \\
in blood agar, chocolate agar, and thioglycolate broth. Results: A total of \\
221 patients ( $\mathrm{n}=224$ eyes) with a mean age of $67 \pm 13$ years were included \\
in the study. Bacteria from the $\left(\mathrm{T}_{0}\right)$ samples were successfully grown in \\
$73.2 \%$ of the thioglycolate agars, $21.0 \%$ of the blood agars, and $19.2 \%$ of \\
the chocolate agars. Compared with $\mathrm{T}_{1}$ samples, the use of povidone-iodine \\
wash translated into a $60.8 \%$ reduction (from $73.2 \%$ to $12.5 \%)$ in coloniza- \\
tion of the conjunctiva $(\mathrm{p}<0.001)$, while no significant difference was \\
found between the $\mathrm{T}_{1}$ and $\mathrm{T}_{2}$ samples. Conclusion: Conjunctival irrigation \\
with a $5 \%$ povidone-iodine solution effectively reduces conjunctival flora \\
and is therefore strongly recommended as a means of preventing postsurgical \\
endophthalmitis following cataract surgery.
\end{tabular}

Keywords: Endophthalmitis/prevention \& control; Cataract extraction; Povidone-iodine; Anti-bacterial agents; Anterior eye segment; Conjunctiva/microbiology; Preoperative care

Trabalho realizado em Assunção - Paraguai.

Fundacion Vision e Central Hospital of the Instituto de Previsión Social. Asunción (Paraguay).

${ }^{2}$ Fundacion Vision. Hugo Nano Foundation e Vision 2020 Latinamerica. Buenos Aires (Argentina).

${ }^{3}$ Sciences Health Research Institute, National University of Asuncion. Asunción (Paraguay).

${ }^{4}$ Sciences Health Research Institute, National University of Asuncion. Asunción (Paraguay).

${ }^{5}$ Sciences Health Research Institute, National University of Asuncion. Asunción (Paraguay).

${ }^{6}$ Department of Ophthalmology, Ludwig-Maximilians

University - Munich (Germany).

${ }^{7}$ Fundacion Vision. Asunción (Paraguay).

${ }^{8}$ Fundacion Vision. Asunción (Paraguay).

Correspondence address: Lorena Quiroga. M. R. Alonso 1626. Sajonia - Asunción - Paraguay

E-mail: dralorenaquiroga@gmail.com

Recebido para publicação em 29.01.2009

Última versão recebida em 19.01.2010

Aprovação em 04.02.2010

\section{INTRODUCTION}

Cataract surgery is one of the most common ophthalmologic procedures, and endophthalmitis, although rare, is one of its most devastating complications. The incidence of this complication has been reported between $0.082 \%$ and $0.16 \%$ in 41,654 eyes operated on for cataract over a 10 -year period $^{(1-2)}$.

It has been shown that organisms isolated from the vitreous of patients with postsurgical endophthalmitis are genetically indistinguishable from those found on the eyelids, conjunctiva, or the nose ${ }^{(3)}$. For example, in the Endophthalmitis Vitrectomy Study, 68\% of cultures grown from 105 patients with postsurgical endophthalmitis yielded intraocular microorganisms indistinguishable from those of the eyelid( ${ }^{(4)}$. Moreover, the conjunctival flora consists of the same organisms that most often cause postsurgical endophthalmitis. In one study of 300 patients of all ages it was found that the conjunctiva was colonized in $48.4 \%$ of the persons tested, predominantly (96\%) by Gram-positive organisms. Of these, $67 \%$ were Staphylococcus, almost 20\% were Corynebacterium, and 9\% were Strep-
\end{abstract}


tococcus $^{(5)}$. In another investigation carried out at the Wills Eye Hospital, cultures of the vitreous from 497 patients with postsurgical endophthalmitis were studied over a period of 11 years (from 1989-2000). Of the positive cultures grown in the last 5 years, 95\% were Gram-positive bacteria, 56\% were coagulase-negative Staphylococcus (Staphylococcus epidermidis $91 \%$ ), and 13\% were Staphylococcus aureus ${ }^{(6)}$.

One of the objectives of prophylaxis against postsurgical endophthalmitis is to reduce the quantity of bacteria on the eyelid and conjunctiva, since it is thought that the majority of causative microorganisms originate there. Povidone-iodine solution is a fast, effective, low-cost disinfectant that attacks a great variety of bacteria, fungi, protozoa, and viruses. Its mechanism of action is the release of free iodine that bonds with essential enzymes and cytoplasmic proteins. The use of $10 \%$ povidone-iodine solution for prophylaxis against endophthalmitis in cataract surgery is performed by applying the solution to the operative field, including the eyelids, eyelashes, and periocular area, followed by washing of the tarsal and bulbar conjunctiva with $10 \mathrm{ml}$ of $5 \%$ povidone-iodine solution; the wiping action itself seems to remove some bacteria ${ }^{(7-8)}$.

The objective of this study was to determine the composition of conjunctival flora in cataract surgery patients and the effect on that flora of presurgical irrigation with povidoneiodine solution.

\section{METHODS}

Patients of all ages who had undergone extracapsular cataract surgery in our department between November 2005 and July 2006 were included in the study. Study variables included demographic data (age, gender, place of origin), growth of cultures in the growth media, the most common bacteria, the presence of surgical complications, the length of surgery, and local or systemic risk factors for endophthalmitis.

Three samples were taken from the inferior conjunctival fornix of the eye to be operated on using moistened cotton swabs. The first sample $\left(\mathrm{T}_{0}\right)$ was taken at the day of surgery before the application of any antibiotic or antiseptic, and was considered the control sample. The second sample $\left(\mathrm{T}_{1}\right)$ was taken after disinfecting the operative field with $10 \%$ povidone-iodine (eyelids, periorbital and hemifacial skin), and 30 seconds after conjunctival washing with $10 \mathrm{ml}$ of $5 \%$ povidone-iodine using a $10 \mathrm{ml}$ syringe without cannula $(5 \mathrm{ml}$ in the superior conjunctival fornix and $5 \mathrm{ml}$ in the inferior conjunctival fornix). The third and final sample $\left(\mathrm{T}_{2}\right)$ was taken after surgery was completed but before administration of any subconjunctival antibiotic.

The control sample $\left(\mathrm{T}_{0}\right)$ was taken by the same observer who performed the cultures throughout the study. The irrigation of the conjunctival fornix was accomplished prior to the blepharostat placement by the operating surgeon, who took samples $\mathrm{T}_{1}$ and $\mathrm{T}_{2}$ under biochemist supervision.

Each sample was grown in 3 different culture media: a 5\% blood agar plate (BAP) and a chocolate agar (CHOC) plate under aerobic microaerophilic conditions, and another chocolate agar plate under anaerobic conditions (ANA). After swabbing these plates, the swabs were then placed in a thioglycolate (THIO) broth. The BAP, CHOC, and ANA plates were observed for 3 days; the thioglycolate medium was observed for 5 days. All culture media were incubated at $35^{\circ} \mathrm{C}$. The date on which bacterial growth was observed was recorded, and the colonies in the culture dishes were counted. Biochemical identification of the isolates was carried out using classic methods.

Data were recorded on an Excel 6.0 electronic spreadsheet and later analyzed using the EPI INFO 2004 statistical package. The chi-square test was used to determine if a significant reduction of microbial contamination occurred after antiseptic washing (a $p$ value $<0.05$ ).

\section{RESULTS}

The study included 221 patients (224 eyes, with samples taken from both eyes for three patients) with a mean age of $67 \pm 13$ years, with $58 \%$ ( $\mathrm{n}=127$ patients) being female and $42 \%(\mathrm{n}=94)$ male, and $46.9 \%$ from rural areas and $52.7 \%$ from urban areas.

The percentage of bacterial growth in the conjunctiva before presurgical irrigation with povidone-iodine $\left(\mathrm{T}_{0}\right)$ was $73.2 \%$ in thioglycolate, $21.0 \%$ in blood agar, and $19.2 \%$ in chocolate agar. Following irrigation with povidone-iodine $\left(\mathrm{T}_{1}\right)$, and following surgery $\left(\mathrm{T}_{2}\right)$, the percentage of bacterial growth fell considerably (Figure 1).

In the $\mathrm{T}_{0}$ samples, the conjunctival flora comprised coagulase-negative Staphylococcus (CoNS) in 105 out of 164 cultures $(64.0 \%)$ and Staphylococcus aureus (SA) in 34 out of 164 cultures (20.7\%), while Streptococcus viridans, Enterococcus, and Corynebacterium were observed at $6.7 \%, 5.4 \%$, and $4.2 \%$, of 164 cultures, respectively (Table 1). The number of samples in which multiple species were identified from the cultures was 23,3 , and 1 for the time periods $\mathrm{T}_{0}, \mathrm{~T}_{1}$, and $\mathrm{T}_{2}$, respectively.

Comparing the bacterial growth in thioglycolate between $\mathrm{T}_{0}$ and $\mathrm{T}_{1}$, the use of povidone-iodine wash translated into a reduction from $73.2 \%$ to $12.5 \%$ in colonization of the conjunctiva $(p<0.001)$, while no significant difference was found between the $T_{1}$ and $T_{2}$ samples.

\section{DISCUSSION}

It is believed that the principal sources of bacteria causing endophthalmitis following cataract surgery are the eyelids and the conjunctiva ${ }^{(2)}$. To our knowledge, no well-executed prospective studies have been performed in Paraguay regarding this complication.

One preventative measure that can be taken is to reduce as much as possible the quantity of conjunctival bacteria on the eyelid prior to surgery. In some countries the use of antibiotics for that purpose has become generalized. In our depart- 


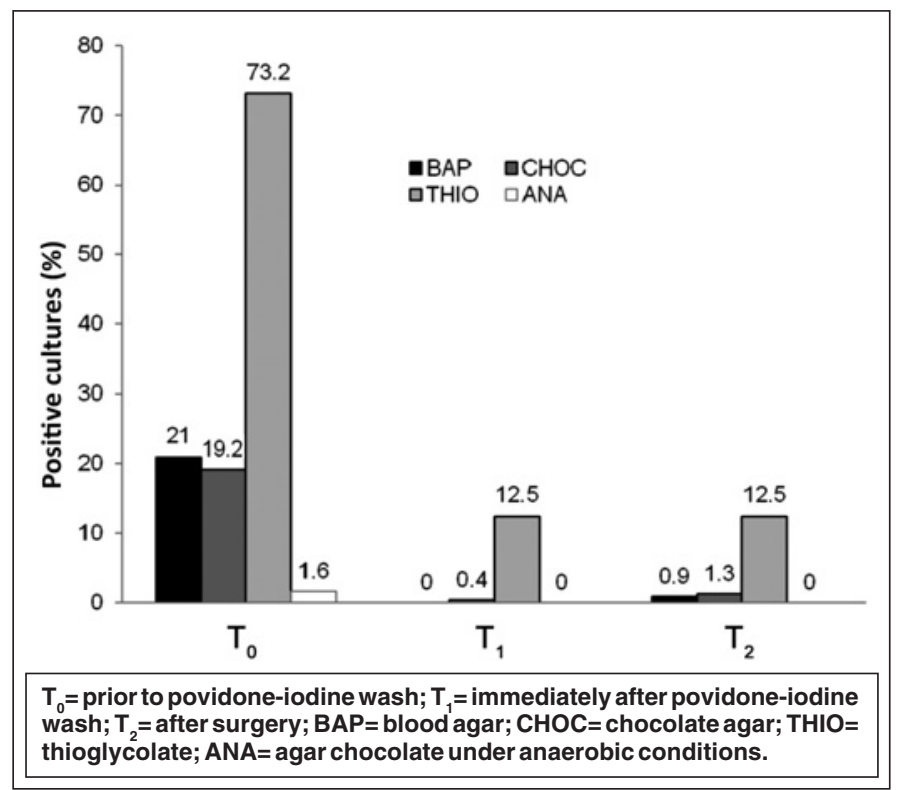

Figure 1 - Percentage of positive cultures in the various media for each of 3 sampling times

ment that practice is not routinely recommended, which is why our results are not confounded by antibiotic use.

The percentage of positive cultures obtained from thioglycolate broth found prior to application of the povidoneiodine $\left(\mathrm{T}_{0}\right)$ was $73.2 \%$, a figure similar to that determined by studies in other countries ${ }^{(7-9)}$. Coagulase-negative Staphylo- cocci (64\% of positive cultures; $46.9 \%$ of eyes) were the most commonly isolated bacteria, although this figure is notably less than that reported in other countries (approximately $75 \%)^{(9-10)}$. Staphylococcus aureus, one of the principal microorganisms causing postsurgical endophthalmitis, was isolated in the study from $15.2 \%$ of eyes, a finding worth noting because its literature prevalence is usually reported as less than $5 \%^{(7,9-10)}$. Perhaps the difference is due to the high prevalence of staphylococcal blepharitis observed in older patients in our setting and frequently inadequate patient compliance with treatment.

Of all measures intended to reduce the risk of endophthalmitis, the most strongly recommended is the presurgical application of 5\% povidone-iodine to the conjunctival fornices because of the significance of the results obtained ${ }^{(11)}$. For example, some authors found a $91 \%$ reduction in the number of colonies and a $50 \%$ reduction in the number of bacterial species when 30 eyes were treated ${ }^{(12)}$. A United Kingdom study of 100 patients, which compared the effects of $1 \%$ and $5 \%$ povidone-iodine solutions, demonstrated that irrigation with the $5 \%$ solution led to a $60 \%$ reduction in colony forming units, compared to a $16.7 \%$ reduction using the $1 \%$ solution. This result was significant $(p<0.05)$, and the difference more evident when the initial bacterial load was higher ${ }^{(13)}$. In our study, irrigation of the conjunctival fornices with $5 \%$ povidone-iodine achieved a major reduction $(60.8 \%)$ in conjunctival flora. This result supports its use in the prevention of postsurgical endophthalmitis.

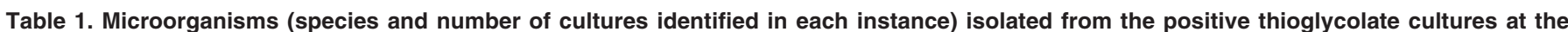

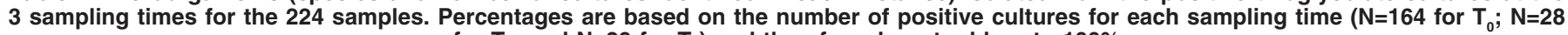
for $T_{1}$; and $N=29$ for $T_{2}$ ) and therefore do not add up to $100 \%$

\begin{tabular}{|c|c|c|c|c|c|c|}
\hline \multirow[t]{2}{*}{ Microorganisms } & \multicolumn{2}{|c|}{$\mathbf{T}_{0}$} & \multicolumn{2}{|c|}{$\mathrm{T}_{1}$} & \multicolumn{2}{|c|}{$\mathbf{T}_{2}$} \\
\hline & $\mathbf{N}$ & $\%$ & $\mathbf{N}$ & $\%$ & $\mathbf{N}$ & $\%$ \\
\hline Coagulase negative Staphylococcus & 105 & 64.0 & 16 & 57 & 16 & 55 \\
\hline Staphylococcus aureus & 34 & 20.7 & 8 & 29 & 9 & 31 \\
\hline Streptococcus viridans & 11 & 6.7 & $\cdots$ & $\ldots$ & $\ldots$ & $\ldots$ \\
\hline Enterococcus spp. & 9 & 5.4 & 2 & 7 & 1 & 3 \\
\hline Corynebacterium spp. & 7 & 4.2 & 2 & 7 & $\ldots$ & $\ldots$ \\
\hline Enterobacter aerogenes & 3 & 1.8 & $\ldots$ & $\ldots$ & $\ldots$ & $\ldots$ \\
\hline Bacillus spp. & 3 & 1.8 & $\ldots$ & $\cdots$ & 4 & 14 \\
\hline Proteus vulgaris & 2 & 1.2 & $\cdots$ & $\ldots$ & $\ldots$ & $\ldots$ \\
\hline Pseudomonas stutzeri & 2 & 1.2 & $\cdots$ & $\cdots$ & $\ldots$ & $\cdots$ \\
\hline Citrobacter koseri & 2 & 1.2 & $\ldots$ & $\ldots$ & $\ldots$ & $\ldots$ \\
\hline E. coli & 2 & 1.2 & 1 & 4 & 1 & 3 \\
\hline Acinetobacter spp. & 1 & 0.6 & $\cdots$ & $\cdots$ & $\cdots$ & $\cdots$ \\
\hline Enterobacter agglomerans & 1 & 0.6 & $\cdots$ & $\ldots$ & $\ldots$ & $\cdots$ \\
\hline Enterobacter cloacae & 1 & 0.6 & $\ldots$ & $\ldots$ & $\ldots$ & $\ldots$ \\
\hline Klebsiella spp. & 1 & 0.6 & $\ldots$ & $\ldots$ & $\ldots$ & $\ldots$ \\
\hline Propionibacterium acnes & 1 & 0.6 & $\cdots$ & $\ldots$ & $\ldots$ & $\ldots$ \\
\hline Proteus mirabilis & 1 & 0.6 & $\cdots$ & $\ldots$ & $\cdots$ & $\cdots$ \\
\hline Pseudomonas aeruginosa & 1 & 0.6 & $\cdots$ & $\cdots$ & $\cdots$ & $\ldots$ \\
\hline Streptococcus spp. & 1 & 0.6 & $\cdots$ & $\ldots$ & $\ldots$ & $\ldots$ \\
\hline $\begin{array}{l}\text { Count of microorganisms isolated from } \\
\text { all thioglycolate cultures }\end{array}$ & 188 & & 29 & & 31 & \\
\hline
\end{tabular}


In Paraguay, povidone-iodine is easy to acquire and apply, and is affordable, making it an ideal prophylactic against postsurgical endophthalmitis. No adverse reactions related to allergies or defects in the surface of the eye have been reported. Endothelial damage due to povidone-iodine has been described in experiments with rabbits ${ }^{(14)}$; however, neither this study nor any others ${ }^{(15)}$ have reported any case of the solution coming into contact with the corneal endothelium of a patient. On the other hand, because there were still a considerable number of positive cultures $(12.9 \%)$ from postsurgery patients in spite of the use of povidone-iodine, it is obvious that methods should be sought to further reduce conjunctival flora. It would also be useful to investigate the susceptibility of the organisms detected to available antibiotics to determine the potential risk they represent. The study employed a relatively large number of patients and utilized rigorous sampling and culture methodologies carried out by a single person, thereby making the results comparable and reproducible.

\section{CONCLUSIONS}

The study shows the usefulness of conjunctival washing with 5\% povidone-iodine solution without antibiotic prophylaxis in reducing conjunctival flora and presumed reduction of postsurgical endophthalmitis following cataract surgery. The obtained results support the recommendation for practice to be used routinely in ophthalmologic surgery due to its antiseptic effectiveness, affordability, and ease of acquisition.

\section{RESUMEN}

Objetivo: Determinar la flora bacteriana de la conjuntiva en los pacientes a ser sometidos a cirugía de catarata y el efecto del lavado prequirúrgico con yodo povidona al 5\% sobre dichos microorganismos. Métodos: Se tomaron 3 muestras del fondo de saco conjuntival del ojo a ser operado de catarata antes $\left(\mathrm{T}_{0}\right)$ de la irrigación de la conjuntiva con $10 \mathrm{ml}$ de yodo povidona al 5\%, como control, inmediatamente después $\left(\mathrm{T}_{1}\right)$ y al término de la cirugía $\left(\mathrm{T}_{2}\right)$. Se realizaron cultivos en agar sangre, agar chocolate y en caldo de tioglicolato. Resultados: Se incluyeron en el estudio 221 pacientes $(n=24$ ojos) con un promedio de edad de $67 \pm 13$ años. El porcentaje de crecimiento bacteriano en $\left(\mathrm{T}_{0}\right)$ fue de $73,2 \%$ en tioglicolato, $21 \%$ en agar sangre y $19,2 \%$ en agar chocolate. Al compararlo con $\left(T_{1}\right)$ el efecto de la yodo povidona se tradujo en una reducción del $60,8 \%$ (de $73,2 \%$ a $12,5 \%$ ) en la colonización conjuntival $(\mathrm{p}<0.001)$. Entre las muestras de los tiempos $\mathrm{T}_{1}$ y $\mathrm{T}_{2}$ no hubo diferencia significativa en cuanto al crecimiento bacteriano. Conclusión: El lavado conjuntival con yodo povidona al 5\% reduce de forma efectiva la flora conjuntival por lo cual se recomienda fuertemente como método preoperatorio, como una de las medidas preventivas de la endoftalmitis posquirúrgica en cirugías de catarata.

Descriptors: Endoftalmitis, prevención \& control; Extracción de catarata; Povidona yodada; Agentes antibacterianos; Segmento anterior del ojo; Conjuntiva/microbiología; Cuidados preoperatorios

\section{REFERENCES}

1. Aaberg TM Jr, Flynn HW Jr, Schiffman J, Newton J. Nosocomial acute-onset postoperative endophthalmitis survey. A 10-year review of incidence and outcomes. Ophthalmology. 1998;105(6):1004-10.

2. Mayer E, Cadman D, Ewings P, Twomey JM, Gray RH, Claridge KG, et al. A 10 year retrospective survey of cataract and endophthalmitis in a single eye unit: injectable lenses lower the incidence of endophthalmitis. Br J Ophthalmol. 2003;87(7):867-9

3. Speaker MG, Milch FA, Shah MK, Eisner W, Kreiswirth BN. Role of external bacterial flora in the pathogenesis of acute postoperative endophthalmitis. Ophthalmology. 1991;98(5):639-49.

4. Bannerman TL, Rhoden DL, McAllister SK, Miller JM, Wilson LA. The source of coagulase-negative staphylococci in the Endophthalmitis Vitrectomy Study. A comparison of eyelid and intraocular isolates using pulsed-field gel electrophoresis. Arch Ophthalmol. 2007;115(3):357-61.

5. García-Sáenz MC, Peral Ortiz De La Torre MJ, De Castro Liébana M, Jiménez Martínez E, García Sánchez JE, Fresnadillo Sánchez MJ. Flora conjuntival según edades. Arch Soc Esp Oftalmol. 1999;56(7):101-5.

6. Recchia FM, Busbee BG, Pearlman RB, Carvalho-Recchia CA, Ho AC Changing trends in the microbiologic aspects of postcataract endophthalmitis. Arch Ophthalmol. 2005;123(3):341-6.

7. González Bandrés C, Carrilero Ferrer MJ, Buznego Suárez L, Garcia Claramunt MA, Mendez Llata M, Paredes B, et al. [Efficacy of toppical povidone-iodine applied the day before cataract surgery to reduce conjunctival flora]. Arch Soc Esp Oftalmol. 2001;86(4):100-5. Spanish.

8. Miño de Kaspar H, Chang RT, Singh K, Egbert PR, Blumenkranz MS, Ta CN. Prospective randomized comparison of 2 different methods of $5 \%$ povidone-iodine applications for anterior segment intraocular surgery. Arch Ophthalmol. 2005;123(2):161-5.

9. de Kaspar HM, Kreidl KO, Singh K, Ta CN. Comparison of preoperative conjunctival bacterial flora in patients undergoing glaucoma or cataract surgery. J Glaucoma. 2004;13(6):507-9.

10. Ta NC, Chang RT, Singh K, Egbert PR, Shiver EM, Blumenkranz MS, et al. Antibiotic resistance patterns of ocular bacterial flora: a prospective study of patients undergoing anterior segment surgery. Ophthalmology. 2003; 110(10):1946-51.

11. Ciulla T, Starr M, Masket S. Bacterial endophthalmitis prophylaxis for cataract surgery. Ophthalmology. 2002;109(1):13-24. Comment in: Ophthalmology. 2003;110(8):1668; author reply 1669. Ophthalmology. 2003;110(8):1667; author reply 1667-8.

12. Apt L, Isenberg S, Yoshimori R, Paez JH. Chemical preparation of the eye in ophthalmic surgery. III. Effect of povidone-iodine on the conjunctiva. Arch Ophthalmol. 1984;102(5):728-9.

13. Ferguson AW, Scott JA, McGavigan J, Elton RA, McLean J, Schmidt U, et al. Comparison of $5 \%$ povidone-iodine solution against $1 \%$ povidone iodine solution in preoperative cataract surgery antisepsis: a prospective randomized double blind study. Br J Ophthalmol. 2003;87(2):163-7.

14. Alp BN, Elibol O, Sargon MF, Aslan OS, Yanyali A, Karabas L, et al. The effect of povidone iodine on the corneal endothelium. Cornea. 2000:19(4):546-50

15. Hale ML. Povidone-iodine in ophthalmic surgery. Ophthalmic Surg. 1970; 1:9-13. 